\title{
Three Novel Mutations in Five Unrelated Subjects with Hereditary Protein S Deficiency Type I
}

\author{
P. H. Reitsma, H. K. Ploos van Amstel, and R. M. Bertina \\ Hemostasis and Thrombosis Research Centre, Department of Hematology, University Hospital, 2300 RC Leiden, The Netherlands
}

\begin{abstract}
A panel of eight unrelated subjects with inherited type I protein S deficiency was screened for mutations in the PROS1 gene. In five subjects an abnormality was found but mutations were not detected in the remaining three subjects. Two subjects shared a $\mathbf{G} \rightarrow$ A transition at position +5 of the donor splice site consensus sequence of intron 10 . Also in two subjects an $A \rightarrow T$ transversion was detected in the stopcodon of the PROS1 gene; this transversion predicts a protein $\mathrm{S}$ molecule that is extended by 14 amino acids. The fifth subject was found to possess two sequence abnormalities. One allele carried a $\mathbf{G} \rightarrow \mathbf{A}$ transition near the donor splice junction of intron 2 , but this abnormality is probably neutral, since it was inherited from the parent with normal protein $S$ antigen levels. In the other allele a single $T$ insertion in codon - 25 was found.

Analysis of platelet RNA showed that only the mRNA with the $A \rightarrow T$ mutation in the stopcodon is present in amounts comparable to wildtype RNA. mRNA from the alleles with the other two mutations was either undetectable or present in greatly reduced amounts. The latter indicates that a mRNA based approach is not feasible for the genetic analysis of protein S deficiency type I. (J. Clin. Invest. 1994. 93:486-492.) Key words: protein $\mathrm{S} \cdot$ mutation $\bullet$ genetics $\bullet$ blood coagulation disorder $\bullet$ venous thrombosis
\end{abstract}

\section{Introduction}

Protein $\mathrm{S}$ is a vitamin $\mathrm{K}$-dependent plasma glycoprotein that functions in the so-called "protein $\mathrm{C}$ anticoagulant pathway" (1). The protein $\mathrm{S}$ molecule shows a typical domain structure consisting of a $\gamma$-carboxyglutamic acid domain, a thrombinsensitive finger, four consecutive EGF-like domains, and a large domain homologous with sex hormone binding globulins $(2,3)$. In human plasma $\sim 60 \%$ of protein $S$ is complexed to C4b-binding protein, a component of the complement pathway; the remaining $40 \%$ is "free" $(4,5)$.

The anticoagulant pathway in which protein $S$ participates

Address correspondence to Dr. P. H. Reitsma, Hemostasis and Thrombosis Research Center, Department of Hematology, University Hospital, Building 1, C2-R, PO Box 9600, 2300 RC Leiden, The Netherlands. H. K. Ploos van Amstel's present address is the DNA Laboratory, Clinical Genetics Center Utrecht, University Hospital, 3501 CA Utrecht, The Netherlands.

Received for publication 23 March 1993 and in revised form 10 September 1993.

J. Clin. Invest.

(c) The American Society for Clinical Investigation, Inc. 0021-9738/94/02/0486/07 \$2.00

Volume 93, February 1994, 486-492 is crucial for normal hemostasis. This is most dramatically demonstrated in homozygous (or compound heterozygous) patients in which there is a complete lack of either protein $\mathrm{C}$ or protein $\mathrm{S}$ in plasma. Such individuals suffer from life-threatening thrombotic complications immediately after birth $(6,7)$. Also heterozygous individuals have an increased risk for thrombosis, albeit at a much higher age and with milder symptoms than homozygotes $(8)$.

The identification of heterozygous individuals with protein $S$ deficiency relies on the measurement of protein $S$ plasma levels of antigen (free or total) and/or activity $(9,10)$. At present a multitude of commercial or home-made tests is used in coagulation laboratories. All these tests suffer from the complication that there is a considerable overlap between the plasma levels in normals and protein S-deficient heterozygotes (8). Under oral anticoagulant treatment, which decreases the synthesis of all vitamin $\mathrm{K}$-dependent plasma proteins, diagnostic uncertainty may be even greater. Furthermore, one should always consider an acquired deficiency of protein $\mathrm{S}$, e.g., during pregnancy (11). A genetic approach aimed at identifying the private mutation in each protein $\mathrm{S}$ deficient kindred would circumvent these diagnostic problems.

Protein $\mathrm{S}$ is encoded by a gene (PROS1) on chromosome 3 that contains 15 exons (12-14). Also on chromosome 3 is a protein $\mathrm{S}$ pseudogene (PROS2) that differs from the active gene by the absence of exon 1 and a $3 \%$ divergence in the nucleotide sequence (12-15). Therefore, if we want to search for point mutations as they are expected to occur in thrombotic families with protein $S$ deficiency $(16,17)$, an assay is needed that discriminates between the two genes. One way of achieving this is to analyze protein S mRNA, after cDNA synthesis, since it is known that only the active gene is transcribed (18). The potential problem with this approach is that any gene defect that interferes with mRNA synthesis and/or processing may remain undetected.

In an alternative procedure one may try to amplify with the PCR reaction each of the 15 individual exons of only the PROS 1 gene. In principle, gene specificity can be obtained by choosing the primers at positions where the active gene and pseudogene display their nucleotide differences. Limitations of this approach are that one is restricted to an analysis of coding regions and splice junctions (but where most mutations are expected to occur), and that one is not free in the choice of the primer sequences. In addition, an exon-based approach is much more time-consuming than the analysis of a single cDNA fragment.

In this report we describe a protocol that allows the specific analysis of the PROS1 gene exons. The protocol was tested in a panel of eight subjects with protein S deficiency type I (19). Five subjects were found to share three unique and novel point mutations, but in three subjects no sequence abnormality was detected. Of the three mutations, only one would have been found if we had relied solely on a RNA-based approach. 
Table I. Nucleotide Sequences of the Primers Used for the Amplification of the PROSI Exons

\begin{tabular}{|c|c|c|c|}
\hline Oligo & Exon & Sequence* & Position $^{\ddagger}$ \\
\hline PS-1-5 & 1 & ITCCGCCGAGGCTCGCTGGG & -146 to -127 \\
\hline PS-1-3 & 1 & TAGGAGCTGCAGCTCTAGAG & 79 to 98 \\
\hline PS-2-5 & 2 & $\overline{\text { GTCATACAATTCATAGGCAG }}$ & -108 to -89 \\
\hline PS-2-3 & 2 & CAGĀAGGAAGTACAGGCTGG & 64 to 83 \\
\hline PS-3-5 & $3^{\S}$ & GTGAAAATGATGGTTTATATG & -125 to -106 \\
\hline PS-3-3 & $3^{\S}$ & AGGTGGAGAGTTAGACAGGA & 78 to 97 \\
\hline PS-4-5 & 4 & CCATGAATTCAGATCAAGTA & -63 to -44 \\
\hline PS-4-3 & 4 & GGTGTACTTTACCTACAGAG & 41 to 60 \\
\hline PS-5/6-5 & $5 \& 6$ & GGCTTCAGGATTTTTATTATAGTA & -87 to -64 \\
\hline PS-5/6-3 & $5 \& 6$ & СTAACTGGGATTATTCTCACAI & 37 to 58 \\
\hline PS-7-5 & 7 & CACAAATCAAGGGTTCTTTGG ${ }^{-}$ & -75 to -55 \\
\hline PS-7-3 & 7 & GATCAGTAATGĀTACCACCA ${ }^{-}$ & 9 to 28 \\
\hline PS-8-5 & 8 & ATAAGATTGAACĀTTTAGGG & -59 to -40 \\
\hline PS-8-3 & 8 & CAGGTGAGAAGTTAAGCATT $\bar{T}$ & 14 to 33 \\
\hline PS-9-5 & $9^{\S}$ & $\overline{T A G T A A C C A A A C A A A A A T G \underline{C}}$ & -97 to -78 \\
\hline PS-9-3 & $9^{\S}$ & 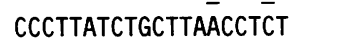 & 31 to 50 \\
\hline PS-10-5 & 10 & AGCITTCTGTATTTCTIACT므 & -50 to -30 \\
\hline PS-10-3 & 10 & ACAGEACTGCATCAAAGTGGG & 29 to 48 \\
\hline PS-11-5 & $11^{\S}$ & GTAÄTACTTGGTTATTTGGTAAI & -41 to -19 \\
\hline PS-11-3 & $11^{\S}$ & САCACĀTATTCAAATCTATTAC & 52 to 71 \\
\hline PS-12-5 & 12 & $\bar{C}$ СTATACTCATAATCGAGCC & -69 to -50 \\
\hline PS-12-3 & 12 & TGGGCACACAG̈TAGAT̄ACTC & 91 to 110 \\
\hline PS-13-5 & $13^{\S}$ & CTGATGCACTTTAGGAGTGC & -54 to -35 \\
\hline PS-13-3 & $13^{\S}$ & $\overline{G T A A A T A C T G C T A T G T A T A C}$ & 55 to 74 \\
\hline PS-14-5 & 14 & GCTTATATTGAATCTTTGCTTCTG & -31 to -19 \\
\hline PS-14-3 & 14 & ATATGCCAATAAATGTCGGT & 138 to 157 \\
\hline PS-15-5 & 15 & CAAGATGCTAAAAGTCTTGG & -49 to -30 \\
\hline PS-15-3 & 15 & GATAGCAAGAGAAGTAAGAATTTC & 182 to 205 \\
\hline
\end{tabular}

* Underlining of nucleotides denotes differences between PROS1 and PROS2. ' Numbering of the position is relative to either the 5 ' or $3^{\prime}$ boundery of each exon (12). ${ }^{\S}$ Exons amplified at an annealing temperature of $53^{\circ} \mathrm{C}$ instead of $55^{\circ} \mathrm{C}$, and at an extension temperature of $67^{\circ} \mathrm{C}$ instead of $72^{\circ} \mathrm{C}$.

\section{Methods}

Patients. Symptomatic probands from eight families with an inherited isolated protein $\mathrm{S}$ deficiency type I were screened for alterations in the PROS1 gene. There was no basis for the selection of the eight probands and they may form a representative sample from families with heredi- tary protein $\mathrm{S}$ deficiency. The initial laboratory diagnosis of an isolated protein $\mathrm{S}$ deficiency type I was made according to previously described criteria; total protein $\mathrm{S}$ antigen, Factor II antigen, and Factor $\mathrm{X}$ antigen were measured as previously described (19-21). Individuals were considered protein S-deficient when their protein $\mathrm{S}$ antigen level was persistently below the lower limit found in normal healthy controls $(0.67$ $\mathrm{U} / \mathrm{ml}$ ). Patients receiving anticoagulant treatment were considered protein $\mathrm{S}$-deficient when their plasma protein $\mathrm{S}$ level was below 0.33 $\mathrm{U} / \mathrm{ml}$, the lower limit for persons using oral anticoagulants. The concentration of other vitamin $\mathrm{K}$-dependent proteins should be within the normal range, as established for healthy volunteers or for patients on oral anticoagulant treatment. The hereditary nature of the deficiency was established by identification of family members with abnormally low protein $\mathrm{S}$ plasma levels.

Genomic DNA amplification. High molecular weight DNA was isolated from peripheral blood leucocytes according to established procedures. The 15 exons that code for the protein S mRNA were amplified with use of the PCR (22). The amplification primers were chosen such that they specifically amplify the PROSI gene (Table I). The PCR was performed in a reaction mixture that contains $500 \mathrm{ng}$ of human genomic DNA, $400 \mathrm{ng}$ of each primer, $150 \mu \mathrm{M}$ of each dNTP, $67 \mathrm{mM}$ Tris/ $\mathrm{HCl}$ (pH 8.8), $6.7 \mathrm{mM} \mathrm{MgCl}_{2}, 10 \mathrm{nM} \beta$-mercaptoethanol, $6.7 \mu \mathrm{M}$ EDTA, $16.6 \mathrm{mM}\left(\mathrm{NH}_{4}\right)_{2} \mathrm{SO}_{4}, 10 \%$ DMSO, and $40 \mathrm{U} / \mathrm{ml}$ Taq-DNA polymerase (Cetus Corp, Emeryville, CA). DNA was amplified in 33 cycles consisting of $1^{\prime}$ denaturation at $94^{\circ} \mathrm{C}, 1^{\prime}$ annealing at either 53 or $55^{\circ} \mathrm{C}$, and $2^{\prime}$ extension at 67 or $72^{\circ} \mathrm{C}$ (see Table I).

cDNA amplification. Platelet-rich plasma was prepared from $25 \mathrm{ml}$ citrated whole blood by centrifugation at $125 \mathrm{~g}$ for $10^{\prime}$. Platelets were collected by centrifugation at $1800 \mathrm{~g}$ for $15^{\prime}$. RNA was extracted from the platelets as described before $(23,24)$. Protein $S$ cDNA was synthesized using oligo cd-2223 as a primer (see Table II). Approximately one tenth of the platelet RNA from one isolation was used in a single cDNA reaction. The cDNA reaction was performed using the Superscript kit according to the instructions of the manufacturer (Bethesda Research Laboratories, Bethesda, MD). A mock reaction without reverse transcriptase functioned as a negative control. Using the cDNA as a template, four overlapping fragments that cover all of the protein $\mathrm{S}$ coding sequence were amplified (for primers see Table II). Each PCR consisted of 38 cycles with $1^{\prime}$ denaturation at $94^{\circ} \mathrm{C}, 1^{\prime}$ annealing at $55^{\circ} \mathrm{C}$, and $2^{\prime}$ extension at $71^{\circ} \mathrm{C}$. Other reaction conditions were as described above for the genomic DNA amplification.

Experiments in which RNA from liver, endothelial cells, and blood platelets was tested for the presence of protein S mRNA were as follows. The cDNA was synthesized using the protein S-specific primer cd-2129, and subsequently amplified using the primer pair cd-2129 and cd-1178. As the template in the cDNA synthesis, $3 \mu \mathrm{g}$ of total RNA was used. The amplification, performed on one tenth of the cDNA reaction, consisted of 35 cycles as described in the previous paragraph.

Oligonucleotide hybridization. Amplified protein $\mathrm{S}$ genomic and cDNA fragments were screened for the $A \rightarrow G$ dimorphism in codon

Table II. Nucleotide Sequence of the Primers Used for cDNA-dependent Amplification

\begin{tabular}{cllc}
\hline Fragment & Oligo & \multicolumn{1}{c}{ Sequence } & Position* $^{*}$ \\
\hline I & CD-2223 & CCCTTCAGCTGTTATTGAAAC & 2223 to 2203 \\
II & CD-2129 & CCAAACTGACGGACATGAGTGAGCTCT & 2129 to 2103 \\
I & CD-1911 & GAAGACCTTCAAAGACAACT & 1911 to 1930 \\
III & CD-1243 & CCTCCAGTTGTGATTTTGGA & 1243 to 1224 \\
II & CD-1178 & ACTTCGTGGTGGAAAGATTG & 1178 to 1197 \\
IV & CD-572 & TCCTTGCCAACCTGGTTTAC & 572 to 553 \\
III & CD-525 & GATGGAAAAGCTTTCTTTTAC & 525 to 544 \\
IV & CD-105 & TCCGCGCGCTTCGAAATGAG & 105 to 124
\end{tabular}

* Numbering of the position is according to sequence No. Y00692 at the European Molecular Biology Laboratory (Heidelberg, Germany) and GenBank (Los Alamos National Laboratory, Los Alamos, NM) (38). 
626 (25). Hybridization was carried out with the allele-specific oligonucleotides PS 626A and PS 626G as previously described (25).

DNA sequence analysis. Amplified DNA was purified by ultra-low gelling temperature gel electrophoresis (21). The DNA was excised and directly sequenced without further purification. For the sequence reaction either a sequencing kit from Boehringer Mannheim (Mannheim, Germany) or Pharmacia AB (Uppsala, Sweden) was used.

\section{Results}

All eight patients are considered to be heterozygotes for protein $\mathrm{S}$ deficiency type I as is shown in Table III. This is evidenced by their total plasma levels of protein $S$ antigen that is $\sim 50 \%$ of what would be expected in a nondeficient individual (plus or minus coumarin treatment).

Screening for mutations. As a first step in the genetic analysis of the protein $\mathrm{S}$ deficient status, we performed a Southern blot analysis of the PROS1 and PROS2 genes by digesting total genomic DNA with the restriction enzyme MspI, and visualizing the genes of interest with a full length cDNA probe. In none of the eight probands abnormalities were found, which indicates that gross gene abnormalities are absent (data not shown).

Amplification of exons 1, 2, and 4 through 15, using the primers and conditions listed as in Table I, leads to PCR fragments that contain only PROS 1 gene sequences. For exon 3 the published sequences do not allow specific amplification of the PROS1 gene, since no differences between PROS1 and PROS2 are known.

The amplified fragments of the eight subjects had the expected length when analyzed by electrophoresis on a $1 \%$ agarose gel (data not shown). This implies that when gene defects are located in those regions they affect only a few base pairs. We therefore carried out a complete sequence analysis of all the amplified fragments for each proband.

Table III summarizes the results of the direct sequence analysis. Proband PS 06 carries a single T insertion at position 2 of codon -25 . This insertion causes a shift in the reading frame that introduces a premature stop at codon -4 . The alteration creates a Ddel restriction site (CTAG $\rightarrow$ CTTAG), which al- lowed easy confirmation of the abnormality by restriction enzyme analysis of relevant PCR fragments. The same proband also carries a $G \rightarrow A$ transition at position +5 of the donor splice junction site of intron 2 . This abnormality is apparently not on the same allele as the codon -25 mutation, since it was not present on one of the alleles of the two affected sons (data not shown).

Probands PS 14 and PS 39 share an A $\rightarrow T$ transversion at the wobble position of the stopcodon. This leads to extension of the normal protein $\mathrm{S}$ molecule with 14 amino acids before a novel stopcodon is reached. This mutation can be visualized easily by restriction enzyme analysis, in this instance with the enzyme AflII. Finally, probands PS 69 and PS 23 both show at the +5 position of the donorsplice site of intron 10 a $G \rightarrow A$ transition. This abnormality results, in the PCR fragment, in the loss of a restriction site for the enzyme Maell, which allowed for easy confirmation of the mutation in the proband and his/her family members.

In the probands PS 77, PS 80, and PS 24 no abnormality could be found in any of the fifteen exons. It is unlikely that this is due to the absence of hereditary protein $S$ deficiency in these families. As illustrated later (in Fig. 2 and Table V), each family counted at least two individuals with plasma protein $S$ levels clearly outside of the normal range.

Cosegregation of the mutation with protein $S$ deficiency. DNA from family members of probands PS $06,14,39$, and 69 was available for a study of the cosegregation of the gene defect with the protein S deficiency. Fig. 1 combined with Table IV shows the results of this analysis. As already mentioned, the abnormality in intron 2 that was found in proband PSO6 probably has little to do with the protein S deficiency, and may represent a neutral sequence variant, since it did not appear in the affected sons (III-1, III-2) of the proband (II-5), whereas the codon -25 mutation did.

All but one of the individuals that carried a mutation were receiving oral anticoagulant treatment for previous thrombotic complications. In all, there seems to be a fair agreement between the occurrence of the mutation and low protein S plasma levels. For instance, in the untreated individual PS 69-II-1 the plasma level of $0.47 \mathrm{U} / \mathrm{ml}$ is clearly consistent with protein $\mathrm{S}$

Table III. Summary of Protein S Antigen Levels and Gene Alterations in Eight Probands with Protein S Deficiency Type I

\begin{tabular}{|c|c|c|c|c|}
\hline Proband* & PS-ag & Nucleotide change & Amino acid change & $\begin{array}{c}\text { Restriction } \\
\text { enzyme }\end{array}$ \\
\hline & $U / m l$ & & & \\
\hline PS- $06^{\ddagger}$ & 0.28 & Codon -25 , ins $\mathrm{T}$ & $\begin{array}{l}-25, \text { Leu } \rightarrow \text { Leu; frameshift, } \\
\text { stop at codon }-4\end{array}$ & +DdeI \\
\hline PS-14 & 0.24 & Codon $636, \mathrm{~A} \rightarrow \mathrm{T}$ & $\begin{array}{l}636 \text {, Stop } \rightarrow \text { Tyr; new stop at } \\
\text { codon } 649, \\
\text { TGIFSLLIIPFCV added }\end{array}$ & -AflII \\
\hline PS-23 & 0.28 & Intron $10,+5, \mathbf{G} \rightarrow \mathbf{A}$ & Donor splice intron 10 & -MaeII \\
\hline PS-24 & 0.25 & None & & \\
\hline PS-39 & 0.22 & Codon 636, $\mathrm{A} \rightarrow \mathrm{T}$ & see PS-14 & - AflII \\
\hline PS-69 & 0.47 & Intron $10,+5, G \rightarrow A$ & see PS-23 & -MaelI \\
\hline PS-77 & 0.25 & None & & \\
\hline PS-80 & 0.35 & None & & \\
\hline
\end{tabular}

* All probands except PS-69 were on oral anticoagulant treatment. ${ }^{\ddagger}$ Proband also carries an apparently neutral sequence variation at position +5 of intron 2 (see Results). $\$$ indicates the appearance, and - indicates the loss of a restriction site. 


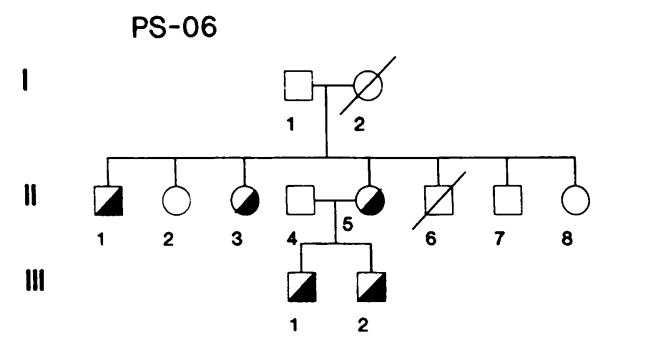

1

II

PS-39

1

II

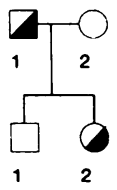

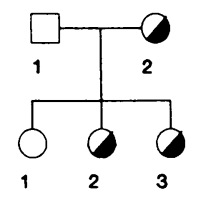

PS-69

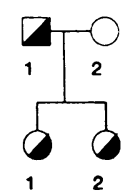

Figure 1. Pedigrees of the four protein S-deficient families in which a candidate gene defect has been identified. Half-filled symbols indicate individuals tested positively for the mutation (see also Table IV).

deficiency type I. When one takes $0.33 \mathrm{U} / \mathrm{ml}$ as the lower limit of normal in stably anticoagulated subjects, 8 out of the 12 remaining mutation carriers should be considered protein $\mathrm{S}$ deficient. Four heterozygous individuals, with plasma levels of $0.34,0.35,0.37$, and $0.37 \mathrm{U} / \mathrm{ml}$, are not protein $\mathrm{S}$ deficient in a strict sense at this blood sampling, but these levels are only

Table IV. Cosegregation of Plasma Protein S Levels with Heterozygosity for a Protein S Mutation

\begin{tabular}{|c|c|c|c|c|c|}
\hline Pedigree & Subject & PS-ag & FII-ag & FX-ag & Heterozygote \\
\hline & & $U / m l$ & $U / m l$ & $U / m l$ & \\
\hline \multirow[t]{8}{*}{ PS-06 } & II-1* & 0.34 & 0.63 & 0.60 & Yes \\
\hline & II-2 & 1.10 & 0.96 & 0.87 & No \\
\hline & II-3* & 0.35 & 0.54 & 0.57 & Yes \\
\hline & II-4 & 1.29 & 0.90 & 0.99 & No \\
\hline & II- $5^{* \ddagger}$ & 0.28 & 0.51 & 0.38 & Yes \\
\hline & II-8 & 1.32 & 1.15 & 1.30 & No \\
\hline & III-1* & 0.29 & 0.58 & 0.54 & Yes \\
\hline & III-2* & 0.30 & 0.52 & 0.49 & Yes \\
\hline \multirow[t]{5}{*}{ PS-14 } & $\mathrm{I}-1$ & 1.37 & 1.50 & 1.12 & No \\
\hline & $\mathrm{I}-2^{*}$ & 0.31 & 0.56 & 0.62 & Yes \\
\hline & II-1 & 1.36 & 1.17 & 1.16 & No \\
\hline & II-2* & 0.29 & 0.47 & 0.43 & Yes \\
\hline & II-3*‡ & 0.24 & 0.37 & 0.33 & Yes \\
\hline \multirow[t]{4}{*}{ PS-39 } & $\mathrm{I}-1^{*}$ & 0.37 & 0.56 & 0.54 & Yes \\
\hline & $\mathrm{I}-2$ & 0.89 & 0.93 & 1.02 & No \\
\hline & II-1 & 0.89 & 1.25 & 1.10 & No \\
\hline & II-2*‡ & 0.22 & 0.60 & 0.46 & Yes \\
\hline \multirow[t]{4}{*}{ PS-69 } & $\mathrm{I}-1^{*}$ & 0.37 & 0.58 & 0.54 & Yes \\
\hline & $\mathrm{I}-2$ & 1.41 & 1.26 & 1.18 & No \\
\hline & II- $1^{\ddagger}$ & 0.47 & 0.93 & 0.98 & Yes \\
\hline & II-2* & 0.33 & 0.57 & 0.50 & Yes \\
\hline
\end{tabular}

* Subjects on oral anticoagulant treatment. ${ }^{\ddagger}$ Proband (see also Table III).

slightly above the lower limit of the normal range (for coumarin-treated patients).

Protein S transcripts in liver, endothelial cells, and blood platelets. The RNA in liver, endothelial cells, and blood platelets (tissues all reported to contain protein $S$ [26-28]), was tested for the presence of protein S mRNA. As shown in Fig. 3, RNA isolated from all three tissues allowed the generation of the expected 953-bp PCR product, and the amount seems to be similar for the three tissues. This suggests that the abundance of protein S mRNA is comparable in liver, endothelial cells, and blood platelets. Next, we analyzed whether the PCR products indeed originated from the PROS1 gene. This was done by restriction analysis with the enzyme MspI, which will discriminate between a PROS1 transcript and a putative PROS2 transcript (18). Fig. 3 shows the results of this analysis for the three celltypes. It is clear from this figure that no PROS2 transcript exists in either celltype, since all of the 953-bp PCR product is cleaved by MspI.

To investigate whether the two PROS1 alleles are codominantly transcribed and accordingly represented in the platelets, the protein S mRNA of an individual who carried both a normal and a PS Heerlen allele (21) was analyzed. The latter allele is characterized by a neutral protein dimorphism $\left(\operatorname{Ser}^{460} \rightarrow\right.$ Pro). Fig. 4 shows the PCR product and a Rsal digest. The PCR fragment contains one invariant RsaI site, and one RsaI site that is polymorphic, depending on the absence or presence of the Heerlen mutation. The invariant RsaI site digests the original 953-bp long PCR product to a 884- and a 69-bp fragment. When the Heerlen allele is present, the 884-bp fragment is halved into two 442-bp fragments. Electrophoresis on an agarose gel shows after ethidium bromide staining equal intensity of the two allele products. This indicates that in normal individuals the two alleles are codominantly transcribed. This is in accordance with the immunological data that show equal contribution of the two protein $\mathrm{S}$ types to the total protein $\mathrm{S}$ antigen (21).

Allele specific gene expression. To determine whether the mutated alleles in the heterozygotes contributed to the mRNA pool in platelets, the $626 \mathrm{G} / \mathrm{A}$ dimorphism (25) was used as a marker for allele-specific transcription. RNA was isolated from 

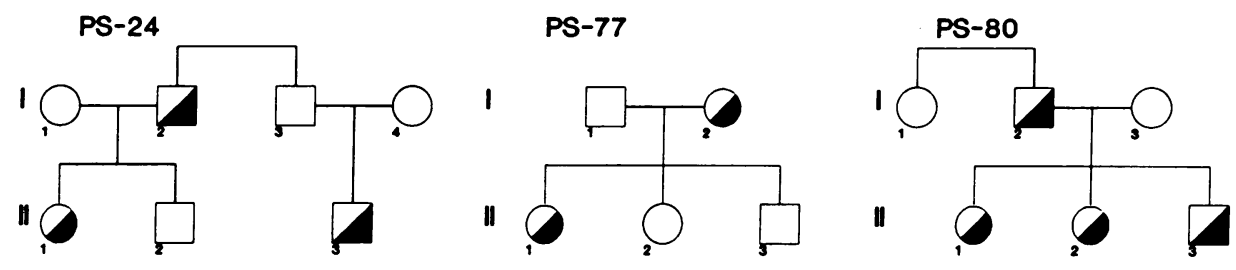

Figure 2. Pedigrees of the three protein S-deficient families in which no candidate gene defect could be identified. Please note that in this figure half-filled symbols indicate individuals with low protein $\mathrm{S}$ plasma levels (see Table $\mathrm{V}$ for the actual levels) rather than individuals that carry a candidate mutation in the protein $S$ gene. the platelets of the probands. The distal region of the protein $\mathrm{S}$ mRNA/cDNA was amplified using the primers cd-1911 and cd-2223. This region contains the $\mathrm{G} / \mathrm{A}$ dimorphism at codon 626 and hybridizes with, respectively, a G- or an A-specific oligonucleotide (25). Similarly, exon 15 of the PROS1 gene that encodes this region was amplified and screened for the $\mathrm{G} /$ A dimorphism. Fig. 5 shows the autoradiogram of the oligohybridization. The probands PS 06, 24, 69, 23, and 14 are heterozygous for the G/A dimorphism. Probands PS 77 and 39 are homozygous $\mathrm{G}$, and proband PS 80 is homozygous $\mathrm{A}$. In contrast, when tested on mRNA/cDNA probands, PS 69 and 23 seem to have lost their A allele and only show the $G$ transcript, whereas proband 06 shows the $G$ transcript and a markedly reduced intensity of the A transcript. The other heterozygous probands (PS 14 and 24) show transcript signals in accordance with their genotype. This indicates that in three out of five informative cases the putative mutations interfere with the steady state level of protein S mRNA in the platelet.

The absence of transcripts from the mutated alleles was also apparent when we tested protein $S$ platelet mRNA for the presence of mutations in the coding region. For patient PS 06 the T-insertion of exon 1 could not be easily identified by direct

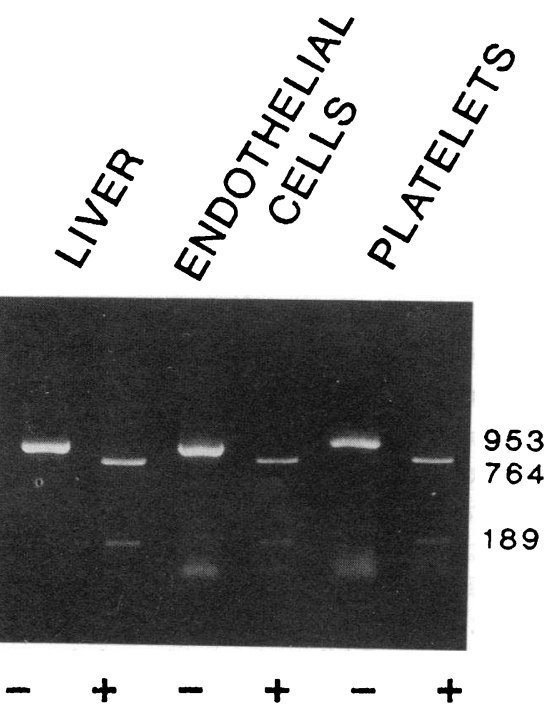

Figure 3. Photomicrograph of a gel showing the presence of protein $\mathrm{S}$ mRNA in RNA extracted from liver, endothelial cells, and blood platelets. The 953-bp long fragments result from the amplification of reversely transcribed protein S mRNA using primers cd-2129 and cd-1178 (fragment II). The lanes marked by + were loaded with the PCR sample after digestion with the restriction enzyme MspI. Please note the complete digestion of the sample, which indicates that in all three tissues only the PROSI gene is transcribed. sequencing of the PCR product of the corresponding protein $\mathrm{S}$ mRNA region: the signal of the aberrant cDNA was greatly reduced. This is in accordance with the reduced intensity of the A transcript as described above. The stop codon mutations in the patients PS 14 and PS 69 did show up with a signal intensity that corresponds to that of the normal transcript (data not shown).

\section{Discussion}

An approach aimed at sequencing all exons and splice junctions of the protein $\mathrm{S}$ alpha gene yielded mutations in five of eight unrelated protein $\mathrm{S}$-deficient subjects. In total, three different mutations were found to segregate with the deficiency. One putative gene defect, $\mathrm{G} \rightarrow \mathrm{A}$ at position 5 in the donor splice junction consensus sequence of intron 2 , did not segregate with low protein S plasma levels and is therefore considered to be a rare but neutral sequence variant. Two gene defects, viz., $G \rightarrow$ A at position 5 of the donor splice consensus sequence of intron 10 and $\mathrm{A} \rightarrow \mathrm{T}$ transcription at position 3 of the stopcodon, each occurred in two probands.

It is interesting to note that two of the three mutations 


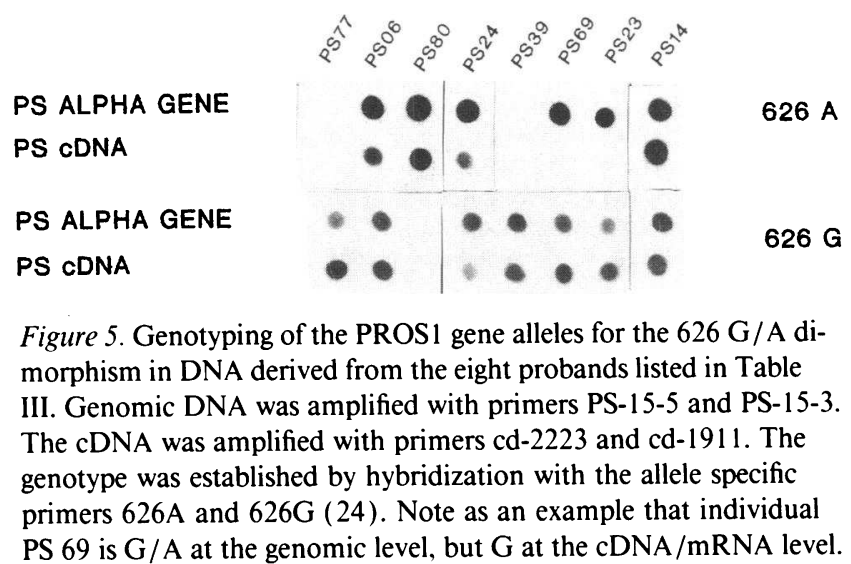

occurred in more than one family. In principle, this may either be due to independent mutational events in the stop codon and the donor splice site of intron 10 , or to the fact that the probands and their family are related somewhere in the past. All the probands are drawn from the Dutch population and therefore founder effects are very likely, as has also been observed in protein $\mathrm{C}$ deficiency (29). On the other hand, the intron $10 \mathrm{G}$ $\rightarrow$ A mutation has occurred in a so-called $\mathrm{CpG}$ dinucleotide that might well be a hotspot for mutation (30).

The cosegregation study serves well to illustrate the importance of genetic studies in protein S-deficient families. Most notably, four individuals that, strictly speaking were not classifiable as protein $\mathrm{S}$ deficient when their plasma was assayed at the time of blood collection for the DNA study did carry a sequence abnormality. The cosegregation data with the intron 2 mutation in PS06 also illustrate that one should be careful in linking sequence abnormalities with disease, and that one should try to sequence as much of the gene as is feasible.

The relationship between the gene defect and the protein $S$ deficiency type $\mathrm{I}$ is immediately clear for the insertion of a $\mathrm{T}$ in exon 1 , since this mutation leads to a premature stop at codon -4 in the prosequence. The mutation in the stopcodon could, in principle, lead to a variant molecule as it predicts an elongated translation product ( 14 amino acids). It is unlikely that such an elongated protein $\mathrm{S}$ molecule exists as a naturally variant, since none of 55 normal individuals tested carried the abnormality in the stopcodon (data not shown). It is of note that the aberrant protein contains a free cysteine at the one but last position and may therefore well be sequestered in the endoplasmatic reticulum or Golgi apparatus due to improper folding $(31,32)$; this would result in a type I classification. Even more uncertain is the interpretation of the mutation in the donor splice junction of intron 10 . One could argue that this mutation interferes with efficient splicing at the 3'-boundary of exon 10 (33). However, a very similar mutation in donor splice junction of intron 2 in PS 06 does not seem to lead to splicing problems. On the other hand, mutations of position +5 in the intervening sequence have been implicated in, e.g., protein $C$ deficiency and hemophilia $\mathrm{B}(34,35)$.

In previous studies, our laboratory has used an exon-based approach for the systematic analysis of gene defects in protein $\mathrm{C}$ deficiency and hemophilia $\mathrm{B}$. This resulted in the identification of sequence abnormalities in more than $90 \%$ of the deficient subjects. This does not seem to be the case for protein $\mathrm{S}$ deficiency, since we are still missing mutations in three out of the 8 probands. One explanation for the apparent absence of mutations would be that the three families are not truly protein $\mathrm{S}$ deficient, but the data in Table $\mathrm{V}$ strongly argue against this possibility. A second explanation could be that the 5 ' end of the PROS 1 gene is still poorly characterized and may be one exon short; this putative exon could harbor mutations. A third explanation may be that on chromosome 3 the protein S gene and pseudogene are tandemly organized and gene conversion events may take place $(36,37)$. If such a conversion event includes the primer sequences, this leads to the mutated allele not being amplified, since in our protocol the primers are selected such that pseudogene sequences are not recognized.

The approach that we originally chose is laborious, since it entails the individual analysis of each of the 15 exons. Therefore, we evaluated an alternative mRNA-based analysis. The first step was to identify a readily available source of mRNA, which was found to be blood platelets. These contain sufficient mRNA for effective amplification after a cDNA reaction. Next, we tested which mutations were detectable in the mRNA. Obviously, the intron 10 mutation should not appear in a normal-size cDNA product. Indeed transcripts of the allele carrying this mutation were not present in the blood platelets. This became clear when we analyzed heterozygosity for a polymorphism in codon 626. Both individuals with the intron 10 mutation were heterozygous when genomic DNA was analyzed, but no heterozygosity was observed when RNA was studied. A similar loss of heterozygosity was observed with the T-insertion in exon 1. Although some of the aberrant transcript was present, it did not readily show up in the sequencing reactions. In contrast with these two mutations, the $\mathrm{A} \rightarrow \mathrm{T}$ transcription in the stopcodon could be easily identified in platelet-derived protein $\mathrm{S}$ cDNA.

In conclusion, genetic studies in protein S deficiency improve the unequivocal identification of heterozygotes. An exon-based approach of identifying mutations in protein $\mathrm{S}$ deficiency is clearly superior to a mRNA-based approach. Nevertheless, three of the eight mutations were not identified. Im-

Table V. Plasma Levels of Protein S, Factor II, and Factor X in Individuals from the Three Families in Which No Mutation in the Protein $S$ Gene Was Identified

\begin{tabular}{|c|c|c|c|c|}
\hline Pedigree & Subject & PS-ag & FII-ag & FX-ag \\
\hline & & $U / m l$ & $U / m l$ & $U / m l$ \\
\hline \multirow[t]{4}{*}{ PS-24 } & $1-2^{* \neq}$ & 0.23 & 0.41 & 0.31 \\
\hline & II-1 & 0.46 & 1.05 & 1.06 \\
\hline & II-2 & 1.07 & 0.97 & 0.95 \\
\hline & II-3* & 0.26 & 0.52 & 0.53 \\
\hline \multirow[t]{2}{*}{ PS-77 } & $\mathbf{I}-\mathbf{2}^{* \neq}$ & 0.28 & 0.66 & 0.68 \\
\hline & II-1 & 0.66 & 1.45 & 1.45 \\
\hline \multirow[t]{5}{*}{ PS-80 } & I-1 & 1.66 & 1.51 & 1.50 \\
\hline & $\mathbf{I}-\mathbf{2}^{* \ddagger}$ & 0.33 & 0.48 & 0.43 \\
\hline & II-1 & 0.59 & 0.90 & 1.00 \\
\hline & II-2 & 0.54 & 1.01 & 0.96 \\
\hline & II-3 & 0.60 & 0.92 & 1.08 \\
\hline
\end{tabular}

Bold lettering indicates individuals considered protein S-deficient. * Subjects on oral anticoagulant treatment. ${ }^{\ddagger}$ Proband (see also Table III). 
provement of the yield awaits the further characterization of the PROS1 gene and the development of a protocol that also takes gene conversions that interfere with gene specific amplifications into account.

\section{Acknowledgments}

We thank Conny Diepstraten, Tineke Krommenhoek-van Es, Denise Kwinkelenberg, and Bert Poort for technical assistance; and C. J. Russcher, M. P. Leemhuis, H. de Korte, J. Bolling, F. J. M. van der Meer, S. Labatto, and R. J. I. Vermeer, from hospitals and thrombosis services throughout the Netherlands, for referring patients to us.

\section{References}

1. Esmon, C. T. 1987. The regulation of natural anticoagulant pathways. Science (Wash. DC). 235:1348-1352.

2. Dahlbäck, B., A. Lundwall, and J. Stenflo. 1986. Primary structure of bovine vitamin K-dependent protein S. Proc. Natl. Acad. Sci. USA. 83:41994203.

3. Joseph, D. R., and M. E. Baker. 1992. Sex hormone-binding globulin, androgen-binding protein, and vitamin $\mathrm{K}$-dependent protein $\mathrm{S}$ are homologous to laminin A, merosin, and Drosophila crumbs protein. 1992. FASEB (Fed. Am. Soc. Exp. Biol.) J. 6:2477-2481.

4. Dahliback, B., and J. Stenflo. 1981. High molecular weight complex in human plasma between vitamin $\mathrm{K}$-dependent protein $\mathrm{S}$ and complement component C4b-binding protein. Proc. Natl. Acad. Sci. USA. 78:2512-2516.

5. Griffin, J. H., A. Gruber, and J. A. Fernandez. 1992. Reevaluation of total, free and bound protein $\mathrm{S}$ and $\mathrm{C} 4 \mathrm{~b}$-binding protein levels in plasma anticoagulated with citrate or hirudin. Blood. 79:3203-3211.

6. Marlar, R. A., R. R. Montgomery, and Broekmans, A. W. 1989. Diagnosis and treatment of homozygous protein C deficiency. J. Pediatr. 114:528-534.

7. Pegelow, C. H., M. Ledford, J. Young, and G. Zilleruelo. 1992. Severe protein $\mathrm{S}$ deficiency in a newborn. Pediatrics. 89:674-677.

8. Engesser, L., A. W. Broekmans, E. Briët, E. P. Brommer, and R. M. Bertina. 1987. Hereditary protein S deficiency: clinical manifestations. Ann. Int. Med. 106:677-682.

9. Comp, P. C. 1990. Laboratory evaluation of protein S status. Semin. Thromb. Haemostasis. 16:177-181.

10. Bertina, R. M. 1991. Hereditary deficiency of protein C and protein S. In Protein C pathway. J. Aznar and F. Espana, editors. Springer Verlag, Berlin. 111-120.

11. Malm, J., M. Laurell, and B. Dahlbäck. 1988. Changes in the plasma levels of vitamin $\mathrm{K}$-dependent proteins $\mathrm{C}$ and $\mathrm{S}$ and of $\mathrm{C} 4 \mathrm{~b}$-binding protein during pregnancy and oral contraception. Br. J. Haematol. 68:437-443.

12. Schmidel, D. K., A. V. Tatro, L. G. Phelps, J. A. Tomczak, and G. L. Long. 1990. Organization of the human protein S genes. Biochemistry. 29:78457852.

13. Ploos van Amstel, J. K., P. H. Reitsma, C. P. E. Van der Logt, and R. M Bertina. 1990. Intron-Exon organization of the active human protein S gene PS and its pseudogene PS $\beta$ : duplication and silencing during primate evolution. Biochemistry. 29:7853-7861.

14. Edenbrandt, C.-M., A. Lundwall, R. Wydro, and J. Stenflo. 199(). Molecular analysis of the gene for vitamin $\mathrm{K}$ dependent protein $\mathrm{S}$ and its pseudo gene. Cloning and partial gene organization. Biochemistry. 29:7861-7868.

15. Ploos van Amstel, J. K., A. L. Van der Zanden, I:. Bakker, P. H. Reitsma, and R. M. Bertina. 1987. Two genes homologous with human protein S cDNA are located on chromosome 3. Thromb. I/acmostas: 58:982-987.

16. Ploos van Amstel, J. K., M. V. Huisman, P. H. Reitsma, J. W. Ten Cate, and R. M. Bertina. 1989. Partial protein $\mathrm{S}$ gene deletion in a family with hereditary thrombophilia. Blood. 73:479-483.

17. Schmidel, D. K., R. M. Nelson, E. H. Broxson, P. C. Comp, R. A. Marlar, and Long, G. L. 1991. A $5.3 \mathrm{~kb}$ deletion including exon III of the protein S- $\alpha$ gene occurs in two protein S deficient families. Blood. 77:551-559.

18. Ploos van Amstel, J. K., P. H. Reitsma, and R. M. Bertina. 1988. The human protein S locus: identification of the PS $\alpha$ gene as a site of liver-protein $\mathrm{S}$ messenger RNA synthesis. Biochem. Biophys. Res. Commun. 157:1033-1038.

19. Deutz-Terlouw, P. P., L. Ballering, A. Van Wijngaarden, and R. M. Bertina. 1989. Two ELISA's for measurement of protein S, and their use in the laboratory diagnosis of protein S deficiency. Clin. Chim. Acta. 186:321-334.

20. Bertina, R. M. 1985. Hereditary protein S deficiency. Haemostasis. 15:241-246.

21. Bertina, R. M., J. K. Ploos van Amstel, A. Van Wijngaarden, J. Coenen, M. P. Leemhuis, P. P. Deutz-Terlouw, I. K. Van der Linden, and P. H. Reitsma. 1990. Heerlen polymorphism of protein $S$, an immunologic polymorphism due to dimorphism of residue 460 . Blood. 76:538-548.

22. Saiki, R. K., S. Sharf, F. Faloona, K. B. Mullis, G. T. Horn, H. A. Ehrlich, and N. Arnheim. 1985. Enzymatic amplification of beta-globulin genomic sequences and restriction site analysis for diagnosis of sickle cell anaemia. Science (Wash. DC). 230:1350-1354.

23. Sambrook, J., E. F. Fritsch, and T. Maniatis. 1989. Isolation of cytoplasmatic RNA from mammalian cells. In Molecular Cloning: A Laboratory Man ual. 2nd ed. Cold Spring Harbor Laboratory Press, Cold Spring Harbor, NY. $7.12-7.15$.

24. Eikenboom, J. C., H. K. Ploos van Amstel, P. H. Reitsma, and E. Briët. 1992. Mutations in severe, type III von Willebrand's disease in the Dutch population: candidate missense and nonsense mutations associated with reduced levels of von Willebrand factor messenger RNA. Thromb. Haemostasis. 68:448-454.

25. Diepstraten, C. M., J. K. Ploos van Amstel, P. H. Reitsma, and R. M Bertina. 1991. A CCA/CCG neutral dimorphism in the codon for Pro 626 of the human protein S gene PS $\alpha$ (PROS1). Nucleic Acids Res. 19:5091.

26. Fair, D. S., and R. A. Marlar. 1986. Biosynthesis and secretion of factor VIII, protein $\mathrm{C}$, protein $\mathrm{S}$, and the protein $\mathrm{C}$ inhibitor from a human hepatoma cell line. Blood. 67:64-70.

27. Stern, D., J. Brett, K. Harris, and P. Nawroth. 1986. Participation of endothelial cells in the protein C-protein $\mathrm{S}$ anticoagulant pathway: the synthesis and release of protein S. J. Cell Biol. 102:1971-1978.

28. Schwarz, H. P., M. J. Heeb, J. D. Wencel-Drake, and J. H. Griffin. 1985. Identification and quantitation of protein $S$ in human platelets. Blood. 66:14521455.

29. Reitsma, P. H., S. R. Poort, C. F. Allaart, E. Briët, and R. M. Bertina 1991. The spectrum of genetic defects in a panel of 40 Dutch families with symptomatic protein $\mathrm{C}$ deficiency Type I: heterogeneity and founder effects. Blood. 78:890-894

30. Cooper, D. N., and H. Youssoufian. 1988. The CpG dinucleotide and human genetic disease. Hum. Genet. 78:151-155.

31. Kassenbrock, C. K.. P. D. Garcia, P. Walter, and R. B. Kelly. 1988 Heavy-chain binding protein recognizes aberrant polypeptides translocated in vitro. Nature (Lond.). 333:90-93.

32. Rothman, J. E. 1989. Polypeptide chain binding proteins: catalytes of protein folding and related processes in cells. Cell. 59:591-601.

33. Shapiro. M. B., and P. Senapathy. 1987. RNA splice junctions in different classes of eukaryotes: sequence statistics and functional implications in gene expression. Nucleic .lcids Re's. 15:7155-7159.

34. Giannelli, F.. P. M. Green. K. A. High, S. Sommer, M. Ludwig, K. Olek, P. H. Reitsma, M. Goossens, A. Yoshioka, and G. G. Brownlee. 1992. Haemophilia B: database of point mutations and short additions and deletions-third edition, 1992. Nuc/cic Acids Res. 20:2027-2063.

35. Reitsma, P. H., S. R. Poort, F. Bernardi, S. Gandrille, G. L. Long, N. Sala and D. N. Cooper. 1993. Protein C deficiency: a database of mutations. Thromb. Ilaemostasis. 69:77-84.

36. Harada, F., A. Kimura, T. Iwanaga, K. Shimozawa, J. Yata, and T. Sasazuki. 1987. Gene conversion-like events cause steroid 21-hydroxylase deficiency in congenital adrenal hyperplasia. Proc. Natl. Acad. Sci. USA. 84:8091-8094.

37. Strachan, T., and P. C. White. 1991. Molecular pathology of steroid 21-hydroxylase deficiency. J. Steroid Biochem. Mol. Biol. 41:827-829.

38. Ploos van Amstel, H. K., A. L. Van der Zanden, P. H. Reitsma, and R. M Bertina. 1987. Human protein S cDNA encodes Phe-16 and Tyr-222 in consensus sequences for the post-translational processing. FEBS (Fed. Eur. Biochem. Soc.) Lett. 222:186-190. 